\title{
Helper Syndrome as a Source of Motivation for Helping Professions in Hospice Care Monika Vachová
}

\begin{abstract}
It is specific for helping professions that the most common motive for choosing them is the relationship towards help as such. Paradoxically, the personality of the helping worker thus becomes a risk factor for professional work and a potential source of problems. The article focuses on one of the causes of motivation to help, the helper syndrome. The aim is to reflect the work of people with the syndrome in hospice care. We want to point out the risks associated with the relationship of the helper to the dying, caring, and survivors, which also affects the functioning of a multidisciplinary team and the fulfilment of hospice care goals.
\end{abstract}

Keywords: palliative care, hospice, helping profession, helper syndrome, saviour complex

\section{Introduction}

The professionalism and stability of the work team is one of the basic preconditions for the fulfilment of the mission and goals of the organisation. In this context, the personal level of each employee and his motivation is an indispensable aspect.

From surveys conducted in the area of helping professions, ${ }^{1}$ we see that, for example, social workers chose their profession because 1) they wanted to work with people (37\%), or 2) they wanted to help them directly (41\%). Almost 4/5 of the respondents stated motivation based on their relationship with other people. ${ }^{2}$ Nurses responded similarly $(68 \%)$ in a recent large-scale questionnaire survey of the Ministry of Health of the Czech Republic. ${ }^{3}$ In addition, hospice care workers have a specific motivation to choose working with the dying based on previous personal

1 Musil points to the lack of a definition of the term helping profession. It simultaneously arises from the description of individual words and their combination. The term is then defined as '... an organised group of workers who provide people in difficulty with a specialised type of support or resources in order to enable them to manage their problems or meet their needs.' Libor MUSIL, Sociální práce a jiné pomáhající obory/profese, in: Encyklopedie sociální práce, ed. Oldřich MATOUŠEK, Praha: Portál, 2013, p. 506.

2 Cf. Markéta ELICHOVÁ et al., Projekt specifického výzkumu Grantové agentury Jihočeské univerzity č. 117/2013/H: Pojetí kvality sociální práce v souvislosti se sebedefinováním sociálního pracovníka a jeho profese, České Budějovice: Teologická fakulta Jihočeské univerzity, 2013. Note: 678 respondents participated in the research survey.

3 The study involved 15,432 non-medical health professionals. Cf. @ MZČR, Největší motivací k práci je pro nelékaře možnost pomáhat druhým lidem, ukázalo dotazníkové šetření MZ (on-line), available at: http://www.mzcr.cz/dokumenty/nejvetsi-motivaci-k-pracije-pro-nelekare-moznost-pomahat-druhym-lidemukazalo-_16575_3970_1.html, published $2^{\text {nd }}$ January 2019, cited 27 $7^{\text {th }}$ January 2020. Research by Heplová, Michálková and Zacharová was carried out with similar results. Cf. Monika HEPLOVÁ and Helena MICHÁLKOVÁ, Motivační prvky v práci sestry, Sestra 11/2010, pp. 30-31. Cf. Eva ZACHAROVÁ, Motivační faktory v sesterském povolání, Sestra 6/2010, p. 30. 
experience of death (most often a close person). ${ }^{4}$ Also, participants in courses related to the processes of dying or grief counselling are mostly motivated to self-education in this area through the personal experience of accompanying a close person in the three stages of dying - pre finem, in finem, post finem. ${ }^{5}$ However, an individual's motives as psychological causes of behaviour can manifest themselves unconsciously. ${ }^{6}$

The personality of the employee influences his view of the client, the framework of his work procedures, the use of methods, strategies, his evaluation, the fact whether the work with the client was or was not successful, etc. ${ }^{7}$ For these reasons, the personality of the helping worker can be described as a risk factor for professional work and a potential source of problems that (taking into account the status of the profession) can be associated with the abuse of power. This also jeopardises the competence ${ }^{8}$ of the helping worker, the stability and the identity of the profession. Consequently, especially in social work, reflexive practice is increasingly emphasised. It is the ability to critically understand one's own influence when working with a client. The aim is to cultivate oneself and improve work. ${ }^{9}$ Navrátil perceives the usefulness of reflexivity in reviewing employee prerequisites and other facts relevant for the employee's entering into a relationship with the client. He points out that 'the helping professional is (also a person) who may mentally want to accept various methodological, managerial or ethical rules but yet he may not succeed.' ${ }^{\prime 0}$ The personality of the worker, his motivation and ability to self-reflect are part of the topic of this study. We will focus on one of the risk motivations of helping professions, the helper syndrome (hereinafter helpless helper / pathological altruist), ${ }^{11}$ specifically in hospice care. The term itself does not yet have a clear definition. ${ }^{12}$ The first and so far most important insight into the problem of the syndrome was described by the German psychoanalyst W. Schmidbauer in 1977 in the book

4 Cf. Šimon JELÍNEK, Setkání s umíráním a smrtí v hospici v kontextu sociální práce, Pražská vysoká škola psychosociálních studií, 2008, p. 40. Cf. Tereza PUDIVÍTROVÁ, Motivace pracovníků pomáhajících profesí k práci v Hospici sv. Jana N. Neumanna v Prachaticích. České Budějovice, 2020, pp. 26-27. Bachelor thesis. University of South Bohemia in České Budějovice. Faculty of Theology. Department of Ethics, Psychology and Charity Work. Thesis supervisor Mgr. Monika Vachová. Note: Research in the field of professional motivation of hospice employees appears in the form of graduate theses of students of health and social sciences. Professional discourse reflecting the motivation of employees who choose work in hospice-type facilities is currently missing.

5 This statement results from the participation of the author in these courses or from her own lecturing in these courses.

6 Professional motivation and its theory form a separate topic which is elaborated in detail by the psychologist and university professor M. Nakonečný. Cf. Milan NAKONEČNÝ, Motivace pracovního jednání a její řizení, Praha: Management Press, 1992; Milan NAKONEČNÝ, Motivace chování, Praha: Triton, 2014, p. 171.

7 Cf. Frederic C. REAMER, Social work values and ethics, New York: Columbia University Press, 1999, p. 11. Note: The results of research also point to differences in the way of solving situations. The emphasis is on communication on an emotional level in women. They have a stronger ability to empathise and are more creative in solving situations. Men focus on objective insight. They have greater determination and less ability to comprehensively perceive the problem. Cf. Markéta ELICHOVÁ, Sociální práce: Aktuální otázky, Praha: Grada, 2017, pp. 128-130. Cf. Radka JANEBOVÂ and Lucie ČERNÁ, Konstrukce žen-klientek a mužů-klientů v praxi sociální práce, Gender, rovné príležitosti, výzkum 2/2008, pp. 37-45.

8 Havrdová mainly deals with the competencies in helping professions in our country. She has created a frequently used model system of competencies, including specifying criteria. Cf. Zuzana HAVRDOVÁ et al., Kompetence v praxi sociální práce: metodická príručka pro učitele a supervizory v sociální práci, Praha: Osmium, 1999, pp. 41-42. Determining and updating the competencies of helping professions is the task of individual associations. For closer study, a comparison of competencies defined by The American Association of Colleges of Nursing and Council on Social Work Education can be recommended. Cf. Joann DAMRON-RODRIGUES, Developing competence for nurses and social workers, The Journal of Social Work Education 3/2008, pp. 27-37.

9 Important initiators of reflective practice include, for example, D. SCHÖN who deals with reflection strategies, especially during the process of working with the client. Cf. Donald SCHÖN, The reflective Practitioner, London: Temple Smith, 1983.

10 Pavel NAVRÁTIL, Reflexivita v posouzení a v sociální práci, in: Reflexivita v posuzování životní situace klientek a klientů sociální práce, ed. Pavel NAVRÁTIL and Radka JANEBOVÁ et al., Hradec Králové: Gaudeamus, 2010, p. 24.

11 Note: The term helper syndrome, i.e., helper syndrome / Helfersyndrom, appears in various synonyms. Let us mention, for example, the messianic complex, the saviour complex, the Samaritan syndrome or the perpetrators of good, a pathological charity. Schmidbauer uses the term helpless helper in this context.

12 Note: We generally define the term 'syndrome' as a set of several typical features that create a certain image, and 'helper' means all helping professions. 
Die hilflosen Helfer: Über die seelische Problematik der helfenden Berufe. ${ }^{13}$ The helper syndrome is characterised by a pathological effort to help. This is not based on the moral principle of selfless service to one's neighbour (altruism) but on the need to heal one's soul. ${ }^{14}$ The helper syndrome can be hidden behind expressions of solidarity, altruism, empathy, etc. A helpless helper is generally characterised by acting in unconscious self-defence. He suppresses personal experiences, emotions, and avoids self-reflection. His need to help and save others leads to self-humiliation and self-harm, and neglect of all social relationships except professional ones. The result is often the development of anxiety, depression, burnout, and many health complications. ${ }^{15}$

The helper syndrome could be viewed from the point of view of many psychological theories, from the point of view of sociology, theology, biology, evolution, etc. Currently, two views are discussed, which are mainly credited to Schmidbauer and Oakley.

(1) Schmidbauer's concept is specifically focused on the reasons for the development of the helper syndrome. He sees the cause in the traumas and unmet needs of childhood. ${ }^{16}$ The goal of his psychoanalytic approach is a gradual 'healing' based on an awareness of childhood experiences and an understanding of their impact on current behaviour. Doležel relates this concept to the concept of deep psychology according to which the choice of future profession is formed in the first five years of a child's life. In addition to this, however, the influence of later psychological development, including mental injuries, is also emphasised.

During this period [i.e., childhood], we take over and internalise the ideals of our parents which we often consider a lifelong commitment. Their violation causes us feelings of guilt. It is these ideals that play an important role in choosing a later profession. In addition to these circumstances, one's own mental injuries suffered during mental development also play a role in choosing a helping profession (...). According to the concept of depth psychology, traumas continue to live as displaced feelings of wrongdoing, anger, fear, inferiority, or as unfulfilled and unacknowledged desires. So until the traumas of childhood and later development become conscious again, there is no hope of a real healing of the helper or his clients. ${ }^{17}$

American psychologists Holmes and Rahe have created a range of life events as significant stressors which, if summed up, can be a significant disturbance of mental balance. The highest number of points (100) was given to the death of a partner. ${ }^{18}$ Death represents a difficult life situation which is related to a change of identity, loss of integrity, a sense of threat characterised by fear, anxiety, etc. Therefore, today, with an emphasis on the individuality of the process, the concept of

13 Wolfgang Schmidbauer pointed out this syndrome as early as 1977. Cf. Wolfgang SCHMIDBAUER, Die hilflosen Helfer: Über die seelische Problematik der helfenden Berufe, Hamburg: Rohwolt Verlag, 1977. His more famous book Das Helfersyndrom. Hilfe für Helfer published in 2007, (cf. Wolfgang SCHMIDBAUER, Syndrom pomocníka: podněty pro duševní hygienu v pomáhajících profesích, Praha: Portál, 2015) contains older and new scientific findings of the original edition, which was published in the Czech Republic in 2000 under the title Psychická úskalí pomáhajících profesí. Cf. Wolfgang SCHMIDBAUER, Psychická úskalí pomáhajících profesí, Praha: Portál, 2000.

14 SCHMIDBAUER, Syndrom..., p. 16.

15 Oakley points out that pathological activism often occurs with disorders such as post-traumatic stress disorder or obsessive compulsive disorder. Cf. Barbara OAKLEY, Ariel KNAFO, Guruprasad MADHAVAN and David Sloan WILSON, Pathological Altruism, Oxford University Press, USA, 2012, pp. 10-13.

16 Cf. SCHMIDBAUER, Syndrom..., pp. 31-32.

17 Cf. Jakub DOLEŽEL, Osobnostní rizika pomáhající praxe: Syndrom pomocníka ve světle biblické moudrosti, Spravedlnost a služba III., in: Sborník odborných príspěvků a studijních textů CARITAS-VOŠ sociální Olomouc, ed. CARITAS-VOŠ sociální Olomouc, 2008, p. 35.

18 Cf. Thomas HOLMES and Richard RAHE, The Social Readjustment Rating Scale, Journal of Psychosomatic Research 2/1967, pp. 213218.Note: After criticism responding to its shortcomings (e.g. types of death - old age or death of a young parent, etc.), a more modern De Meus scale was created where, however, the evaluation of the death of a close family member is also in the highest positions of stressors. Cf. Libor MíČEK and Vladimír ZEMAN, Učitel a stres, Brno: Masarykova univerzita, 1992, pp. 57-61. 
distinguishing between 'normal' / uncomplicated and complicated / pathological grief is abandoned. Nevertheless, aspects that can complicate the processing of the death of a loved one remain in one's consciousness. ${ }^{19}$ Despite the individuality of the grief process, Špaténková points out that it is undesirable for a grief counsellor (including every hospice worker) not to be fully able to cope with the death of a loved one. Otherwise, there is a high probability of inability to decide whether he is acting professionally. The risk is, for example, coping with death by ineffective strategies using ego-defence mechanisms. ${ }^{20} \mathrm{~A}$ worker affected by loss may use sublimation and projective identification in this context. Both of these unconscious defensive attitudes, in turn, combine the personal experience of losing a loved one with subsequent charity. Research shows ${ }^{21}$ that the actual experience of the death process of a loved one or the accompanying is a frequent motivation for work in hospice care.

(2) While the above focus is on the helpless helper, Oakley addresses the problem of the pathological altruist in relation to the consequences of his actions. This concerns the target person or group of people who should be assisted, as well as the effects of acting in the wider social environment, that is the family, work collective, other social ties of a helpless helper, the whole society. ${ }^{22}$ The emergence of the syndrome of pathological altruism stems from evolutionarily beneficial manic behaviour. ${ }^{23}$ Her concept is close to a systemic approach in social work. Each cause/action has a consequence and changing the interaction rules is assumed to cure the problem cause. The therapy of a pathological activist does not lie in the psychoanalytic retrospection of a helpless helper. It is based on the search for alternatives to change his actions or communication patterns that lead to the solution of consequences/problems that have arisen. That is, we do not ask the question 'why' but, above all, 'how' (what solution will cause a change in the behaviour of the pathological activist).

In the following part of the text, we want to point out the motivations of a helpless worker for choosing a helping profession, specifically in hospice care. ${ }^{24}$ Here, too, we cannot objectively assess whether the helper syndrome in hospice care workers arose after the incomplete processing of the death of a loved one, or manifested itself earlier, and the encounter with death only motivated them to choose work with the dying in hospice care. ${ }^{25}$ Specifically, we will address the specific potential manifestations of the syndrome in hospice workers which, to a large extent, threaten not only the dying person and his family but the entire multidisciplinary team and the goals of hospice care. Each chapter is presented by an instrumental case study written in the form of casuistry. These are model examples that are fictional due to the ethical side of the issue. The strategy of combining several anonymised real case reports from the practice of hospice care in the Czech Republic was used to write these cases. ${ }^{26}$ Their main purpose is to point out the symptoms common in pathological altruists who work in hospice care, to understand important aspects of

19 Note: This division is used, for example, by Ulrichová and Špaténková (Kubićková). Cf. Monika ULRICHOVÁ, Hledání smyslu ve smrti a utrpení: Zdravotně sociální aspekty konce života v perspektivě existenciální analýzy, Ostrava: Moravapress, 2014, pp. 116-123. Cf. Naděžda KUBÍČKOVÁ, Zármutek a pomoc pozůstalým, Praha: Institut sociálních vztahů, 2001.

20 Cf. Naděžda ŠPATÉNKOVÁ, Poradenství pro pozůstalé, Praha: Grada Publishing, 2013, p. 23.

21 Note: See the research mentioned in the introduction and practical examples in the following chapters.

22 Cf. OAKLEY, Pathological Altruism..., pp. 3-9.

23 Cf. Barbara OAKLEY, Concepts and implications of altruism bias and pathological altruism, PNAS 2/2013, pp. $408-415$.

24 Note: Among the helping professions of hospice care we include nurses, social workers, doctors, psychologists, clergy and other workers in direct care (for example, workers in social services, caregivers, physiotherapists, etc.). Cf. Lukas RADBRUCH and Sheila PAYNE a kol., Standardy a normy hospicové paliativní péče v Evropě, Praha: Cesta domů a Česká společnost paliativní medicíny, 2010, pp. 45-46.

25 Note: Therefore, the examples given in the individual chapters also do not take into account early childhood.

26 These case reports were collected by participatory observation and non-standardised interviews during a meeting of mobile hospice directors in November 2018. The data were interpreted based on their analysis. The model examples in this article only illustrate the ways in which these workers act, their internal motives and attitudes, external motives (circumstances that motivated them to choose a profession, etc.). 
their actions, and to illustrate the effects of their actions in three relational areas: (1) the dying and their caregivers, (2) the survivors, and (3) the work team. Due to the uniqueness of this topic of hospice helper syndrome,${ }^{27}$ these examples can also provide space for reflection/self-reflection.

\section{Helper Syndrome in the Care of the Dying and their Loved Ones}

Example no. 1: Ms Alena works as a nurse in home hospice care. She is always very kind, empathetic, creative, self-sacrificing to the dying and to their carers (that is, most often to the family). She tries to support them fully. She actively seeks various ways to help. She organises charitable help for families in material need. She mediates various therapeutic activities for the dying. For many families, she doesn't just do what is expected of her, but she does everything for them, she cannot say 'no'. She commutes to 'her dying ones' frequently (beyond her job duties). In this context, she has violated the internal rules of work organisation several times. For example, she has given carers her private phone number so that they could contact her 'day and night' exclusively. She tries to maintain private contact with many families even after the end of hospice care, even beyond the hospice-coordinated care of survivors. She tries to make clients her closest friends.

Internally, she constantly fights for recognition and for being in favour, for praise. She only likes to commute to places where people reciprocate her affection: they give her positive feedback. She would like to keep these families in her own care. She feels irreplaceable there. She uses a lot of physical contact, often without self-reflection, that is, whether or not the dying or those caring want it to such an extent. Therefore, in some families there is a conflict because of this. She also has problems with addressing the clients. In an effort to establish a close relationship, despite the differences in organisational rules, she offers to call each other by first names. She calls clients 'grandmother' or 'grandfather'.

Working in a hospice is close to her heart and she has sacrificed her whole current life to it. In her own personal life, she neglects herself. She has literally 'pushed her own family to the sidelines'. The family 'must understand' this, they must adjust themselves to her profession and the great demands which are associated with it. After all, she does a meritorious activity. In her free time, she visits families she has previously cared for, and organises charity events. The cause and motivation to work in the hospice was the tragic death of her sister. However, she never talks about this event.

When providing palliative care, the goal is the quality of life of the patient in accordance with his expressed wishes and attitudes, being the previously expressed wishes. ${ }^{28}$ The basic rule of autonomy 'volenti aegroti suprema lex' ${ }^{29}$ applies here. If we omit the legal aspect of the relationship between the hospice worker and clients, ${ }^{30}$ the mutual ethical aspect of this relationship is generally dealt with by ethical codes of helping professions and codes or standards of hospice associations and individual organisations. ${ }^{31}$ They define a relationship based primarily on 1) human dignity,

27 Note: The topic of the helper syndrome in hospice care has not yet been sufficiently developed in the Czech or foreign professional literature.

28 Cf. Zákon č. 372/2011 Sb., o zdravotních službách, \$36.

29 That is, the will of the patient is the supreme law. Cf. Jolana TĚŠINOVÁ et al., Medicínské právo, Praha: C. H. Beck, 2011, pp. 36-49. Prokop and Kabelka state that 'a dilemmatic situation arises in the autonomy of the subject if the patient has a reduced ability to think rationally with a change the quality of consciousness. However, this does not change his or her subjective perception of the level of pleasant (safe) or unpleasant (stressful) feelings. (...) The autonomy of an individual can manifest itself on various levels - current desires, but also life preferences which are known in advance.' Jiří PROKOP and Ladislav KABELKA, Etika paliativní péče, in: Paliativni medicína pro praxi, ed. Ondřej SLÁMA et al., Praha: Galén, 2007, p. 319.

30 Hospice care in the Czech Republic is only marginally addressed by law. Cf. Zákon č. 372/2011 Sb., o zdravotních službách, $\$ 44 a$.

31 In the Czech Republic, there are currently three associations regarding palliative medicine institutions and member hospices. All have their own code of ethics or standards: Asociace poskytovatelů hospicové paliativní péče, Česká společnost paliativní medicíny České lékařské společnosti Jana Evangelisty Purkyně and Fórum mobilních hospiců. At the international level, there is the European Association for Palliative Care. 
and 2) a focus on quality of life. ${ }^{32}$ Realising both values can be complicated for a helpless worker. Based on Hermann Stenger, Doležel develops three risky motives for helping workers in the helping professions: (1) gain recognition and love, (2) have power over other people, and (3) have a 'share in life. ${ }^{33}$ Using his helping activity, the pathological altruist unconsciously compensates for his own inability to experience and express his emotions, to fulfil his needs and goals. There is an emotional dependence of the helpless helper on the dying person and his family/carer. The helper's dependence, including the hidden need to process his own experiences ${ }^{34}$ leads him to try to evoke similar emotional experiences in his clients in the hope that they will be able to accept and process these emotions. This denies professionalism and dignity/respect for man in the sense of Kant's categorical imperative according to which man can never be only a means but an end in himself. Thus, paradoxically, the helpless helper loses sight of the object of the helping professions which is the person himself with his vulnerability, with his problem.

The dependence of a helpless helper is in conflict with the position of the dying/sick which is connected with the tendency to an asymmetry of the relationship. That is, especially in healthcare, we still encounter the paternalistic model of the relationship between health care provider and patient. The helpless helper unknowingly exploits this asymmetric situation by delegating his addiction to the people he cares for. Helpless workers often seek unnecessary control over clients. This can intrude on the privacy of the dying person and his family, limiting his personal will. In practice, then, adults may be treated as children. ${ }^{35}$ Thus, this can bring the situation of violating human dignity and the principle of 'volenti aegroti suprema lex' and the situation of violating 'lege artis' procedures. According to Sláma, the 'lege artis' procedure involves jointly formed decisions on the basis of the full knowledge of the dying person. There must be a cooperative relationship between the worker and the dying person. ${ }^{36}$

Dependence also means that a helpless helper may feel threatened if other people enter into a relationship between his client/caregiver. Due to the consolidation of the position of a helpless worker in the family, the roles of other members of the multidisciplinary team may be taken over or verbal attacks may be made directly against other team members (see example no. 3).

\section{The Helper Syndrome in the Care of the Grieving}

Example no. 2: For Ms Monika, working with the grieving is the only purpose of life. A major turning point in her life was the death of her husband. She could accompany him when he was dying in an in-patient hospice. She talks about it very often. Today, she sees it as the most beautiful day in

32 The most up-to-date version of the standards was created during the cooperation of all associations in the Czech Republic. Consensually, it was adopted only by two out of three associations (Fórum mobilních hospiců and Česká společnost paliativní medicíny). Besides the two principles, it emphasises individuality, autonomy, patient will, multidisciplinarity, and complexity of care. Cf. Standardy mobilní specializované paliativní péče v ČR, Praha: Česká společnost paliativní medicíny ČLS JEP a Fórum mobilních hospiců, 2019, p. 8. Cf. also Fórum mobilních hospiců, Etický kodex: Fórum mobilních hospicu, čl. IV., cf.. RADBRUCH, Standardy..., pp. 21-23. Cf. Ondřej SLÁMA et al, Standardy paliativní péče 2013, Praha: Česká společnost paliativní medicíny České lékařské společnosti Jana Evangelisty Purkyně, 2013, p. 5. Cf. Asociace poskytovatelů hospicové paliativní péče, Standardy hospicové paliativní péče, Praha: APHPP, 2016, p. 3. Both values are also addressed in detail in Recommendation of the Council of Europe No. 1418/1999 on 'Protection of the human rights and dignity of the terminally ill and the dying. Cf. Doporučení Rady Evropy č. 1418/1999 'O ochraně lidských práv a důstojnosti nevyléčitelně nemocných a umírajících.

33 Cf. DOLEŽEL, Osobnostní..., pp. 32-47.

34 'People sometimes become helpers because it is difficult for them to get help. For this reason, they delegate dependence on their clients'. SCHMIDBAUER, Syndrom..., p. 8.

35 Cf. KOP ŘIVA, Lidský..., p. 18.

36 Cf. Ondřej SLÁMA and Lukáš PRUDIL, Právní aspekty paliativní péče, in: Paliativní medicína pro praxi, ed. Ondřej SLÁMA et al., Praha: Galén, 2007, p. 322. 
her life that changed her. This event motivated her to care for the grieving whom she accompanies privately today. Ms Monika has no children and refuses to have a new relationship. In her opinion, her life's mission is precisely to accompany the grieving, who need her. It is clear from her story how difficult it is for her to break free from her focus. She does not talk about anything else. She perceives that everyone she meets may be the one who needs her help. Ms Monika is very friendly, helpful, energetic, and motherly. She has already acted as a grief counsellor in several organisations. Her methods of work have been misunderstood, and they were not appreciated by other members of the multidisciplinary team. She believes she performed her role competently. She has accompanied the dying in finem holding them by the hand. She has also given a lot of care to the grieving, who have found emotional support with her.

From the team's point of view, she has repeatedly preferred herself as the only competent person. She has disturbed intimate moments when the family wanted to say goodbye to the dying in solitude. Sometimes she completely 'substituted' them. Unconsciously, she has clung to every emotional expression of the grieving. She tries to convince them about their need to be accompanied. She has tried to help to those who were not interested, who managed their situation on their own or with the support of loved ones. While working with the grieving, she has refused their progression and could not 'leave' any of them. She has tried to keep in touch and build strong relationships that have outgrown the role of counsellor. She has been unable to reflect on her actions in the context of the goals in the process of accompanying the grieving.

The standard of specialised hospice care is, among other things, care for the grieving. ${ }^{37}$ It is clear from many case studies ${ }^{38}$ that grief counselling is a very specific area. It concerns both subjects of the relationship in an existential way. It confronts them with their own mortality, the topic of personal helplessness, their own experiences of death of loved ones. Špaténková may therefore state that grief counselling

... requires not only specialised knowledge and skills but also a different approach in relation to clients. More than any other, helping counselling (or helping relationship) depends primarily on the personal competencies of the counsellor. (...) In addition, the mortality grief counsellor should be balanced with his own, aware of his own losses, and his reactions to the themes and situations of dying, death, and grieving. ${ }^{39}$

It follows from the above that the personality of the grief counsellor requires enormous skills in the field of introspection, self-reflection, and continuous supervision. These affect the quality of the counselling process and especially develop the personality of the worker and his ability to implement ethical principles of the profession into practice. ${ }^{40}$ However, a helpless worker is characterised by a limited ability to self-reflection and a negative attitude towards supervision. In practice, lay help and support for the grieving (one-off and regular) is provided by any member of the hospice team, most often by a nurse, social worker, carer, or doctor. This is due to the fact

37 Cf. RADBRUCH, Standardy..., p. 25. Note: Care of grieving ones is one of the indicators of specialised hospice care. It stays in contrast to the general form of hospice care provision which does not offer continuous care to the grieving by core specialist workers who are part of a multidisciplinary team.

38 Cf. ŠPATÉNKOVÁ, Poradenství..., p. 19.

39 ŠPATÉNKOVÁ, Poradenství..., pp. 19-20, 25.

40 American Council on Social Work Education defines (as the first three requirements) abilities to practise the profession: (1) the ability to think critically, (2) the ability to implement ethical principles in practice, and (3) the ability to professionalise one's personality. Cf. Oldřich MATOUŠEK, Úvod: Cíle a úrovně sociální práce, in: Metody a řízení sociální práce, ed. Oldřich MATOUŠEK, Praha: Portál, 2013, p. 15. 
that direct care workers often interact with the loved ones during the care of the dying person and are also the first to meet the grieving in the post finem stage. The meeting of the grieving ones with a psychologist, psychotherapist, grief counsellor, or member of the clergy usually takes place after an expression of interest. It is especially suitable when the grieving shows some factors of complicated mourning. ${ }^{41}$

In practice, therefore, every worker from the helping profession in hospice care will meet the grieving. Yet this help requires a lot of knowledge, skills, and personal prerequisites. Musil and Doležalová present four levels of implementation of this help: (1) psychological, (2) pragmatic, (3) informational, and (4) economic. ${ }^{42}$ Based on ongoing interactions, the personality of the helping worker enters into a relationship with the grieving (see Introduction). At the same time, through the relationship, the spiritual aspects of the life of the grieving are deepened. In this context, Doležel points out that, according to the International Federation of Social Workers, each intervention takes place in five contexts, including a spiritual context. ${ }^{43}$ Therefore, the abovementioned four levels of implementation of help should be supplemented by levels (5) social and (6) spiritual. In the abovementioned case study, we point out some risks associated with the helpless worker's care of the grieving. In the case of a helpless helper, there are situations in which the worker is motivated by the need for help but, paradoxically, he tries to delay the termination of the contract with the grieving as much as possible, or tries to change the roles in the relationship between the two entities into friendship. The reason for such procedures is again the worker's need for dependence (see point 1 ). ${ }^{44}$ Therefore, he solves ever-emerging situations without supporting the grieving in their own activities, that is, to make the most of their own abilities and possibilities in their primary social environment. Thus, this procedure of a helpless worker does not correspond to the goal of grief counselling which is primarily focused on support of the ability to shape one's own life without the deceased, to build new relationships. ${ }^{45}$ The frequency of meetings and their form ${ }^{46}$ should be based on the real needs of the grieving.

The helpless worker has a repeated tendency to form an exclusive competence for help to the grieving. A worker who does not sufficiently reflect upon the symptoms of complicated mourning is not motivated to delegate the grieving to the care of another competent professional in time. Failure to comply with the principle of subsidiarity, involving not only a multidisciplinary team but also external experts, can have existential consequences. This 'inaction', especially for the grieving who have risky symptoms of complicated mourning, can lead to the development of mental disorders, addictions, various forms of aggression, and the risk of suicide.

\section{The Helpless Helper as a Member of a Multidisciplinary Team}

Example no. 3: Ms Ludmila is a nurse with twenty years of experience. She has been working in hospice care for the last two years. Before that, she worked for a long time in a home for the elderly. The motivation to change the workplace was her own accompaniment of dying family members,

41 Cf. ŠPATÉNKOVÁ, Poradenství..., p. 22.

42 Zdeňka DOHNALOVÁ and Libor MUSIL, Př́nos sdružení Dlouhá cesta pro matky a rodiny vyrovnávající se se ztrátou dítěte, Sociální práce / Sociálna práca 2/2008, p. 108.

43 DOLEŽEL, Osobnostní..., p. 39.

44 Another reason, striving for the highest possible number of interactions between the employee and the client, may be, paradoxically, the system of redistribution of subsidies within the Ministry of Labour and Social Affairs and grant activities. In this context, state social policy can contribute to the denial of the principles of the helping professions, and thus to its own denial.

46 That is, individual, pair, family, group. 
especially her mother and father-in-law. Through this experience, Ms Ludmila perceives the meaning of working in hospice care. She wishes as many people as possible could have their end of life as her loved ones in her care. Another motivating factor for choosing a job for Ms Ludmila was her faith in God. According to her, the hospice offers a greater opportunity to realise practical love for one's neighbour, i.e., for the dying. She can offer and mediate God's peace and mercy to them even before death. She is very selfless to the dying and their families. She needs to see herself as the one who helps the most, and the most professionally. Also, she needs to be loved by the dying and their loved ones the best - more than other team members. She strives for the perfection which she requires not only for herself but also for others around her, including her family. She transfers these high demands, that is, she expects others to strive for perfection too.

She has problems with her co-workers and superiors. Internally, she fights not only for the recognition of clients but also for the favour and praise of her superiors. If she receives positive feedback from a family, she likes to brag about it. Concerning other team members, however, she can tell their every little failure to the superiors. She fights especially against those who are able to do something or to know something better. She often secretly depreciates them and creates an image of herself as a perfect person. On the contrary, as soon as someone says something she does not like, she immediately needs to defend herself, to oppose him. She manifests herself more as an 'individual player'. Working with other team members is difficult for her. She does not accept the roles of other members of the multidisciplinary team. She believes that she can help many of the families better at a given time. She thinks that other members of the team could break the trust that the dying and their family have built in her. In a group, she needs to have the main say or at least space for her own opinion, and she does not accept different opinions. Silence is a big problem for her. She cannot be in a community where there is a moment of silence. She always has the urge to have the main say or to ask questions. She also has an answer to every question right away. She is unable to reflect on the recommendations of her superiors. After all, she 'means everything in a good way' and 'does not want anything for herself'. She refuses supervisions, she does not realise her problem. She always blames other people for the causes of conflicts.

The above examples represent a helpless worker as an 'individual player' who does not accept teamwork or subsidiarity due to his sense of exclusive competence. He prefers to work independently in order to gain personal merit, recognition, etc.

This is related to taking the roles of other members of a multidisciplinary team, incompetent actions, or even securing a position by humiliating other team members. Similar behaviour of a helpless worker then becomes a source of professional conflicts in the team and in relation to superiors (for example, in the context of not accepting strategies for the development of the organisation or organisational guidelines). The bio-psycho-socio-spiritual model of caring for the dying person and his loved ones can only be fully realised through functional cooperation within a multidisciplinary team.

The pathological activist is also characterised by the need for constant verbal communication which, according to Schmidbauer, can be understood as a defence against awareness of displaced personal experiences.

Moreover, the helper syndrome can be amplified through faith in Jesus Christ. The Christian-motivated helper accepts Jesus as an example of realising practical love to one's neighbour. However, the pathological activist, when practising this 'type of love', does not reflect the freedom of each person as the highest value and gift of God. ${ }^{47}$

47 Cf. Papežská rada pro spravedlnost a mír, Kompendium sociální nauky církve, p. 97. Note: In the Christian sense, freedom is a gift from 


\section{Conclusion}

In this paper, we have reflected upon the attitudes of helpless helpers and the consequences of their actions in hospice care which can affect the dying, their loved ones, the grieving, and the multidisciplinary team. We have pointed out a problem that can be a conscious or unconscious motivation of many workers in the helping professions.

The topic of the helper syndrome requires much deeper attention in the field of research. This article does not contain all its accents. Above all, it is also necessary to think further about the possibilities of work with pathological activists. At the individual level, it is necessary to learn to recognise, reflect, and 'treat' the syndrome - that is, to cultivate one's personality. At the organisational level, the importance of the role of professional codes of ethics and competencies (which form a guide and framework for ethical practice) is emerging. Dealing with helper syndrome can also bring practical benefits. It lies especially in the fact that 'we can improve the mental hygiene of people in the helping professions and help them build stable motivation. ${ }^{48}$ This affects, among other things, the stability of the team and suitable working conditions for meeting the goals of hospice care.

Can helper syndrome be understood as a failure of professional hospice care? Do we not confuse this syndrome with every philanthropically motivated work of helping professions or spontaneous involvement in helping organisations? Both have an irreplaceable role in helping organisations. In conclusion, this study offers more questions than answers.

It should be added that Schmidbauer perceives the helper syndrome as something normal, that is, something that simply exists in the helping professions. ${ }^{49}$ But the difference between help and rescue will need to be reflected upon. Elisabeth Kübler-Ross, co-founder of the world hospice care movement, describes it:

\footnotetext{
But one has to realise the difference between rescuing someone - that is, to change something in a person's life, to correct it forcibly - and helping someone, i.e., to be here for him when he is at a certain stage of humility, and asks for specific help himself. And the line between a rescuer and a real helper, a well-functioning neighbour, is drawn in a very thin line..$^{50}$
}

A real failure of the professionalism in hospice care would occur in this context if we accepted the false motivations of employees without a reflection upon this problem, without finding suitable solutions and the possibilities of overcoming arising consequent problems.

\section{Contact}

\section{Monika Vachová MA}

University of South Bohemia in České Budějovice

Faculty of Theology

Department of Ethics, Psychology and Charity Work

Kněžská 8, 37001 České Budějovice

monikaflidrova@seznam.cz 